\title{
Investigation of Correlation Between Research Self- Efficacy and Academic Performance in Iranian Students of Health Sciences
}

\section{Alireza Khatony}

Kermanshah University of Medical Sciences

\section{Parisa Shiri}

Kermanshah University of Medical Sciences

Maryam janatolmakan

Kermanshah University of Medical Sciences

Seyyed Mohsen Azizi ( $\nabla$ smohsenazizi@yahoo.com )

Arak University of Medical Sciences

\section{Research Article}

Keywords: Research Self-Efficacy, Academic Performance, University Students

Posted Date: September 15th, 2021

DOI: https://doi.org/10.21203/rs.3.rs-861015/v1

License: (c) (i) This work is licensed under a Creative Commons Attribution 4.0 International License. Read Full License 


\section{Abstract \\ Purpose}

One of the most important concepts in educational psychology is self-efficacy. Self-efficacy in the learning and research process can play an important role in the success of students. Therefore, the purpose of this study was to investigate the level of research self-efficacy in students and its correlation with academic performance.

\section{Methods}

In this correlation study, 210 Iranian students of health sciences participated. The self-efficacy in research measure (SERM) and grade point average (GPA) was used for data collection. Data analysis was conducted using SPSS version 18.

\section{Results}

Most of the students used internet and library resources for more than 3 hours and less than 1 hour per day, respectively. In addition, students mostly used the PubMed database. The mean research selfefficacy score among students was $183.12 \pm 46.54$ out of 297 . There was a significant difference between the mean research self-efficacy score and age group $(F=2.103, P \leq 0.01)$. Research self-efficacy had a significant correlation with academic performance $(r=0.648, P \leq 0.01)$.

\section{Conclusion}

In this study, research self-efficacy of students was at a moderate level. Research self-efficacy showed associations with academic performance. In general, the findings suggest that research self-efficacy is very important in students' educational-research performance. Therefore, educational and psychological interventions are necessary to enhance the research self-efficacy beliefs.

\section{Introduction}

One of the key issues in higher education is academic performance $(1-3)$. Improving the level of academic performance in students is one of the important priorities of universities (4). Evidence suggests that there is an association between students' academic performance and psychological, behavioral, and social factors $(5,6)$. Self-efficacy (SE) is one of the most important psychological factors for improving students' academic performance (7-9). SE in Bandura's social cognitive theory is defined as "individual's belief in their abilities and skills in performing an action" (10). In other words, SE is a feeling of competence and ability to adapt to difficult situations and issues of personal and social (10-12). Selfefficacy beliefs play an important role in promoting the performance of health science students (13). The 
results of the study by Klassen and Klassen (2018) indicated that in recent years, research on selfefficacy beliefs in health professions students has increased (13). In this regard, Olivier et al. (2019) showed that SE has a significant correlation with academic achievement (9). Galyon et al. (2012) also reported that SE predicts the level of learners' participation in the learning process and the quality of their performance in exams (14). In addition to academic performance, it is important to improve students' research skills (15-19). Researchers have emphasized that increasing research culture and researchbased learning in healthcare students is a vital priority in the healthcare system (20). University students are one of the most important factors in socio-economic development. They play a vital role in the publication of scientific studies and participation in research projects. In this regard, students' belief in their self-efficacy is a key factor in their research performance (21). One of the concepts related to SE is research self-efficacy (RSE). RSE reflects students' beliefs about their abilities to doing scientific research (22). According to social cognitive theory, individuals' beliefs about their abilities have a positive effect on having a better performance (23). Studies show that there is a positive and significant correlation between RSE and research performance and academic performance $(24,25)$. In addition, RSE has a significant relationship with research intention $(26,27)$. Researchers believe that students with low RSE are not confident about their research abilities. In addition, their research performance is poor. In contrast, students with a high RSE believe in their abilities. As a result, they are successful in research activities $(25,28-30)$. Evidence from studies suggests that some health science students are poor in some research skills such as computer skills and quantitative research skills (25). They also do not believe in their ability to do research (22). Thus, it is necessary to assess the level of RSE in students to design training programs and workshops (31). Considering to the few studies have been conducted between SER and academic performance this study was designed (25) The purpose of the present study was to investigate RSE in students and its correlation with academic performance. In this study, we want to answer the following questions:

1. What is the level of RSE in health science's students?

2. Is there any significant difference between the mean RSE score and demographic variables?

3. Is there any significant relationship between RSE and students' academic performance?

\section{Methods}

\section{Study design}

This correlation study was conducted from October 2019 to January 2020.

\section{Sample and Sampling}

The study sample consisted of nursing, medical, and health students who were studying at Kermanshah University of Medical Sciences in 2019-2020 academic years. Sample size was determined based on a correlation coefficient formula $(n=210)$. The participants were selected by stratified random sampling method. The response rate to the questionnaires was $100 \%$. The inclusion criteria in this study were 
studying at the second semester of 2019-2020 academic years, consent to participate in the study, studying in one of the fields of nursing, medicine or health and completing the questionnaires fully.

\section{Instruments}

Data were collected using a self-designed scale and the self-efficacy in research measure (SERM) (32). A self-designed scale was used to obtain demographic information, including sex, age, and field of study. This scale included other questions about grade point average, hours of using of the internet, hours of using the library, reason or purpose of using the internet, and frequency of use of the scientific database.

The Persian version SERM was used to evaluate RSE. The SERM consists of 33 items and developed by Phillips and Russell (1994). The psychometric properties of this questionnaire have been confirmed in Iranian students (33). In addition, the validity and reliability of this questionnaire in Phillips and Russell (1994) study were confirmed (32). Internal consistency of the scale in this study was 0.960 (Cronbach's $a=0.960)$.

SERM consists of four sub-scales practical research skills (eight items), Research design skills (eight items), writing skills (nine items) and quantitative and computer skills (eight items). The method of scoring SERM is that each item is given a score from 0 to 9 . A score of 0 indicates no confidence in research ability, and a score of 9 reflects complete confidence in research ability. The total score of the questionnaire was from 0 to 297. We also used indicator GPA to determine students' academic performance. Many studies have used the GPA to assess academic performance $(1,34,35)$.

\section{Study Procedures}

Initially, the design and implementation permission was obtained from the KUMS's Research Deputy. Then, the researcher attended the schools of KUMS and obtained the list of students. The list was numbered and then students were selected according to the table of random numbers. After selecting the samples, the researcher referred to the students according to the classroom schedule. The purpose of the study was stated to the students. Then, the questionnaire was given to the students who were willing to participate in the study. Finally, questionnaires were collected after completion.

\section{Ethical considerations}

The current study has been confirmed by the ethics committee of KUMS with the code of IR.KUMS.REC.1398.212. In order to comply with ethical considerations, written informed consent was obtained from samples. The students were assured about the confidentiality of their demographic and answers.

\section{Data analysis}

The statistical package for the social sciences (SPSS for Windows 18.0, SPSS Inc., Chicago, IL) was used to conduct the data analyses. Frequency, percentage, mean and standard deviation were used for 
descriptive analysis. Independent sample t-test, one way ANOVA and Pearson's correlation ( $r$ ) were used for analysis of questions. To compare the mean RSE score in male and female students, the independent sample t-test was used and the one-way ANOVA test was used to compare the mean RSE score according to variables of age and field of study. Pearson's Correlation $(r)$ test was used to investigate the correlation between RSE and academic performance. Significance level was set at less than $0.05(P \leq 0.05)$.

\section{Results}

The demographic characteristics of the students are shown in Table 1. In total, 210 students participated in the study. $51.0 \%$ of the students were male $(n=107)$ and $49.0 \%$ were female $(n=103)$. The majority of students $(n=91,43.3 \%)$ were in the age range of $27-31$ years with a mean age of $29.26 \pm 4.96$ years. Most of the students $(n=76,36.2 \%)$ were studying at the health field (Table 1$)$.

Table 1

Comparison of mean research self-efficacy score in term of demographical characteristics students

\begin{tabular}{|c|c|c|c|c|}
\hline Variable & & $\mathbf{N}(\%)$ & Mean (SD) & Statistical Test \\
\hline \multirow[t]{2}{*}{ Sex } & Men & $107(51.0)$ & $184.53 \pm 45.48$ & \multirow[t]{2}{*}{$\mathrm{T}=0.446, P=0.893$} \\
\hline & Women & $103(49.0)$ & $181.66 \pm 47.80$ & \\
\hline \multirow[t]{4}{*}{ Age range } & $22-26$ & $67(31.9)$ & $188.22 \pm 56.27$ & \multirow[t]{4}{*}{$\mathrm{F}=2.103, P=0.005^{\star \star}$} \\
\hline & $27-31$ & $91(43.3)$ & $188.19 \pm 38.69$ & \\
\hline & $32-36$ & $33(15.7)$ & $167.42 \pm 50.5$ & \\
\hline & $37 \leq$ & $19(9.0)$ & $168.10 \pm 2617$ & \\
\hline \multirow[t]{3}{*}{ Field } & Nursing & $71(33.8)$ & $181.52 \pm 48.61$ & \multirow[t]{3}{*}{$\mathrm{F}=0.70, P=0.933$} \\
\hline & Medicine & $63(30.0)$ & $184.44 \pm 43.40$ & \\
\hline & Health & $76(36.2)$ & $183.52 \pm 47.43$ & \\
\hline
\end{tabular}

The majority of students used the internet $(N=124,59.0 \%)$ and library resources $(N=130,61.9 \%)$ for more than three hours and less than an hour per day, respectively. $46.7 \%$ of the students used the internet to "search for scientific sources and information". PubMed $(N=85,40.5 \%)$ and Scopus $(N=15,7.1 \%)$ were the most and least databases used by students, respectively (Table 2 ). 
Table 2

Frequency of students' use of information resources

\begin{tabular}{|c|c|c|}
\hline Item & & $N(\%)$ \\
\hline \multirow[t]{3}{*}{ Hours of using of the internet per day } & $<1$ hour & $16(7.6)$ \\
\hline & $1-3$ hour & $70(33.3)$ \\
\hline & $>3$ hour & $\begin{array}{l}124 \\
(59.0)\end{array}$ \\
\hline \multirow[t]{3}{*}{ The purpose of using the internet } & $\begin{array}{l}\text { Search for scientific sources and } \\
\text { information }\end{array}$ & $98(46.7)$ \\
\hline & online shopping & $52(24.8)$ \\
\hline & Social Network & $60(28.6)$ \\
\hline \multirow[t]{3}{*}{ Hours of using of the library per day } & $<1$ hour & $\begin{array}{l}130 \\
(61.9)\end{array}$ \\
\hline & $1-3$ hour & $52(24.8)$ \\
\hline & $>3$ hour & $28(13.3)$ \\
\hline \multirow{5}{*}{$\begin{array}{l}\text { Frequency of use of the scientific } \\
\text { databases }\end{array}$} & PubMed & $85(40.5)$ \\
\hline & Scopus & $15(7.1)$ \\
\hline & Web of Science & $28(13.3)$ \\
\hline & Science Direct & $61(29.0)$ \\
\hline & Clinical Key & $21(10.0)$ \\
\hline
\end{tabular}

The results of the first question of the study showed that the mean RSE score was $183.12 \pm 46.54$ out of 297. Among the subscales of RSE, The highest and lowest scores of students were related to writing skills (54.34 \pm 14.56$)$ and quantitative and computer skills (39.91 \pm 12.61$)$ respectively (Table 3$)$.

Table 3

Mean (SD) students' research self-efficacy and its sub-scales

\begin{tabular}{|llll|}
\hline Research Self-efficacy & Number of item & $\begin{array}{l}\text { Cronbach's } \\
\text { alpha }\end{array}$ & Mean (SD) \\
\hline Research Design Skills & 8 & 0.864 & $42.83 \pm 11.98$ \\
\hline Practical Research Skills & 8 & 0.866 & $46.04 \pm 12.29$ \\
\hline Quantitative and Computer Skills & 8 & 0.872 & $39.91 \pm 12.61$ \\
\hline Writing Skills & 9 & 0.911 & $54.34 \pm 14.56$ \\
\hline Total score & 33 & 0.960 & $183.12 \pm 46.54$ \\
\hline
\end{tabular}


The results of the second question of the study indicated that the mean RSE score in male students $(184.53 \pm 45.48)$ was higher than female students $(181.66 \pm 47.80)$. However, this difference was not statistically significant. The mean RSE score in students of 22-26 years $(188.22 \pm 56.27)$ was higher than other students, which showed a statistically significant difference $(F=2.103, P \leq 0.01)$. In terms of field of study, the mean RSE score in medical students $(184.44 \pm 43.40)$ was higher than nursing and health students. This difference was not statistically significant (Table 1). In relation to the third question of the study results showed that there was a significant positive correlation between RSE and academic performance of students $(r=0.648, P \leq 0.01)$. Furthermore, there was a positive and significant correlation between all subscales of RSE with academic performance. This correlation was significant at level $P \leq 0.01$ (Table 4).

Table 4

Correlation coefficients between variables study

\begin{tabular}{|c|c|c|c|c|c|c|}
\hline Variable & 1 & 2 & 3 & 4 & 5 & 6 \\
\hline Research Design Skills & 1 & & & & & \\
\hline Practical Research Skills & $0.851^{\star \star}$ & 1 & & & & \\
\hline Quantitative and Computer Skills & $0.763^{\star \star}$ & $0.618^{\star \star}$ & 1 & & & \\
\hline Writing Skills & $0.876^{\star *}$ & $0.870^{\star \star}$ & $0.570^{\star \star}$ & 1 & & \\
\hline Research skill self-efficacy & $0.963^{\star \star}$ & $0.923^{\star \star}$ & $0.810^{\star \star}$ & $0.923^{* \star}$ & 1 & \\
\hline Academic Performance (GPA) & $0.607^{\star \star}$ & $0.555^{\star \star}$ & $0.626^{\star \star}$ & $0.560^{\star \star}$ & $0.648^{\star \star}$ & 1 \\
\hline${ }^{* *} P \leq 0.01$ & & & & & & \\
\hline
\end{tabular}

\section{Discussion}

In the current study, we investigated the level of RSE and its correlation with academic performance in Iranian students. In addition, the mean RSE score was compared in terms of demographic characteristics. Based on the findings of this study, students showed moderate level of RSE. The findings from some studies suggest that students' belief in their research skills is low $(22,36)$. Results of another study showed that the RSE of students is at an acceptable level (25). In our opinion, the ability of educators to teach the principles of research and methodology, access to scientific resources on the internet and the library, interest in research and perception of the educational-research environment are among the factors affecting the quality of students' research skills $(27,37)$.

According to the findings of current study, the score of quantitative and computer skills was lower than other dimensions. Tiyuri et al. (2018) also showed that students are weak in computer skills and quantitative research (25). In this regard, Odaci (2013) showed that computer self-efficacy is a predictor of RSE (21). Another of our findings showed that the mean RSE score in male students was higher than 
female students. However, this mean difference was not statistically significant. In this regard, the results of some studies indicated that there was no significant difference between the score of RSE in male and female students (38-40). Nevertheless, Wright and Holttum (2012) in a study concluded that masculine identity is correlated with higher RSE and more desire to do research (26). In addition, the results of some studies have shown that women in some disciplines, such as medical sciences and social sciences, tend to do research and participate in scientific activities (41). In short, gender is an important factor in psychological studies. Researchers believe that male and female students have different psychological characteristics $(42,43)$. Therefore, these psychological differences should be considered by educational planners.

The students that were in the age range of 22-26 years had a higher score of RSE compared to other students. This difference was statistically significant. In this regard, Lambie and Vaccaro (2011) have shown that the age variable has a significant effect on students' understanding of the research teaching environment (16). Additionally, Some researchers believe that younger students have more adaptability and skill to use new technologies in research and search (16). Research skills and RSE should be promoted in all of students. One of the important aspects of lifelong learning is information search skills (44). Therefore, the culture of lifelong learning must be developed in universities. The development of a lifelong learning culture plays an important role in enhancing students' willingness to do research. The mean RSE score in medical students was slightly higher than nursing and health students. This mean difference was not statistically significant. This part of our findings was consistent with the findings of Ashrafi-Rizi et al. (2015) (38).

This research determined a significant relationship between RSE and academic performance. This finding was consistent with the findings of other studies $(14,25)$. Individuals with a high belief in RSE exhibit better performance. Based on the results of one study, SER has a significant effect on increasing interest in research and acquiring research knowledge (37). The results of another study showed that there is a significant correlation between higher RSE and higher interest research (27). Additionally, findings from other studies emphasized that the acquisition of research skills and RSE has a positive role in predicting learner aspirations for research careers (45). We believe that students should have sufficient knowledge and skills in research. They must also have a positive belief in their skills. Empirical studies show that educational interventions have a significant effect on promoting $\operatorname{RSE}(13,42)$. Therefore, educational and psychological interventions should be considered by educational managers and planners in universities.

There are some limitations in this study that should be noted. The present study was conducted in some disciplines of health sciences. Caution should be taken when generalizing the results to other disciplines. It is recommended that this study be conducted at other universities and disciplines. This study assessed only four research skills using the Phillips \& Russell scale. Future studies can assess other skills. Researchers can use other scales such as the research self-efficacy scale $(46,47)$; research attitudes measure (48); research self-efficacy (49); clinical research appraisal inventory (50). The current study had methodological limitation. This study was cross-sectional. Thus, it is not possible to infer causal relationship between the variables. 


\section{Conclusion}

The RSE of health sciences students was at a moderate level. There was significant difference between the mean RSE score and age groups. The RSE was significantly correlated with academic performance. Students with high level of research skills and positive feelings of RSE can play an effective role in solving the challenges of the global community. Students' belief in their research self-efficacy plays an important role in improving their academic performance. Therefore, in the educational-research environment of universities, students should be encouraged to participate in research projects. Additionally, effective teaching is a vital factor in improving students' research skills. Therefore, it is necessary to provide educational infrastructure in universities. Increasing interaction between students and faculty members, increasing students' engagement in scientific-research projects and psychological interventions are among the strategies to increase students' research self-efficacy. Therefore, it is necessary to focus on these strategies in educational programs.

\section{Declarations}

\section{Ethics approval and consent to participate}

The study was approved by research ethics committee of KUMS (IR.KUMS.REC.1398.212). According to the Helsinki Declaration, students were informed of the voluntary nature of this study. We received written informed consent from all students.

\section{Consent for publication}

Not Applicable.

\section{Availability of data and materials}

The data of this study are available upon request due to some ethical limitations. If someone wants to request the data from this study, they can contact Parisa Shiri (p.nurse9797@gmail.com).

\section{Competing interests}

The authors declare there are no competing interests.

\section{Funding}

No financial support for this study.

\section{Authors' contributions}

SMA and AKH wrote the manuscript, Study data were collected by PSH and MJ; SMA conducted the statistical analysis, the manuscript was revised by all authors. All authors approved the final manuscript. 
Acknowledgements

We appreciate the deputy of research and technology of KUMS and the students who participated in this research.

\section{References}

1. Azizi SM, Soroush A, Khatony A. The relationship between social networking addiction and academic performance in Iranian students of medical sciences: a cross-sectional study. BMC psychology. 2019;7(1):28.

2. HAYAT AA, SALEHI A, KOJURI J. Medical student's academic performance: The role of academic emotions and motivation. Journal of Advances in Medical Education \& Professionalism. 2018;6(4):168.

3. Guàrdia J, Freixa $M$, Peró $M$, Turbany $J$, Cosculluela $A$, Barrios $M$, et al. Factors related to the academic performance of students in the statistics course in psychology. Quality and Quantity. 2006;40(4):661-74.

4. Bayat $B$, Salehiniya $H$. Assessing academic success rate and related factors among the students. Journal of education and health promotion. 2019;8.

5. Paloș R, Maricuţoiu LP, Costea I. Relations between academic performance, student engagement and student burnout: A cross-lagged analysis of a two-wave study. Studies in Educational Evaluation. 2019;60:199-204.

6. Chen JJ-L. Relation of academic support from parents, teachers, and peers to Hong Kong adolescents' academic achievement: The mediating role of academic engagement. Genetic, social, and general psychology monographs. 2005;131(2):77-127.

7. Hwang MH, Choi HC, Lee A, Culver JD, Hutchison B. The relationship between self-efficacy and academic achievement: A 5-year panel analysis. The Asia-Pacific Education Researcher. 2016;25(1):89-98.

8. Zajacova A, Lynch SM, Espenshade TJ. Self-efficacy, stress, and academic success in college. Research in higher education. 2005;46(6):677-706.

9. Olivier E, Archambault I, De Clercq M, Galand B. Student Self-Efficacy, Classroom Engagement, and Academic Achievement: Comparing Three Theoretical Frameworks. Journal of youth and adolescence. 2019;48(2):326-40.

10. Bandura A. Self-efficacy: toward a unifying theory of behavioral change. Psychological review. 1977;84(2):191.

11. Artino AR. Academic self-efficacy: From educational theory to instructional practice. Perspectives on medical education. 2012;1(2):76-85.

12. Dumbauld J, Black M, Depp CA, Daly R, Curran MA, Winegarden B, et al. Association of Learning Styles with Research Self-Efficacy: Study of Short-Term Research Training Program for Medical Students. Clinical and translational science. 2014;7(6):489-92. 
13. Klassen RM, Klassen JR. Self-efficacy beliefs of medical students: a critical review. Perspectives on medical education. 2018;7(2):76-82.

14. Galyon CE, Blondin CA, Yaw JS, Nalls ML, Williams RL. The relationship of academic self-efficacy to class participation and exam performance. Social Psychology of Education. 2012;15(2):233-49.

15. Murdoch-Eaton D, Drewery S, Elton S, Emmerson C, Marshall M, Smith JA, et al. What do medical students understand by research and research skills? Identifying research opportunities within undergraduate projects. Medical Teacher. 2010;32(3):e152-e60.

16. Laidlaw A, Aiton J, Struthers J, Guild S. Developing research skills in medical students: AMEE Guide No. 69. Medical teacher. 2012;34(9):754-71.

17. Riley SC, Morton J, Ray DC, Swann DG, Davidson DJ. An integrated model for developing research skills in an undergraduate medical curriculum: appraisal of an approach using student selected components. Perspectives on medical education. 2013;2(4):230-47.

18. Imafuku R, Saiki T, Kawakami C, Suzuki Y. How do students' perceptions of research and approaches to learning change in undergraduate research? International journal of medical education. 2015;6:47.

19. Devi V, Abraham RR, Kamath U. Teaching and assessing reflecting skills among undergraduate medical students experiencing research. Journal of clinical and diagnostic research: JCDR. 2017;11(1):JC01.

20. Rahman S, Majumder MAA, Shaban SF, Rahman N, Ahmed M, Abdulrahman KB, et al. Physician participation in clinical research and trials: issues and approaches. Advances in medical education and practice. 2011;2:85.

21. Odaci $\mathrm{H}$. The role of computer self-efficacy, self-esteem, and subjective well-being in predicting research self-efficacy among postgraduate students. The Asia-Pacific Education Researcher. 2013;22(4):399-406.

22. Lev EL, Kolassa J, Bakken LL. Faculty mentors' and students' perceptions of students' research selfefficacy. Nurse education today. 2010;30(2):169-74.

23. Ozer EM, Adams SH, Gardner LR, Mailloux DE, Wibbelsman CJ, Irwin Jr CE. Provider self-efficacy and the screening of adolescents for risky health behaviors. Journal of Adolescent Health. 2004;35(2):101-7.

24. Davari A, Danesh Kazemi A, Aghili H, Mozafari F. The Evaluation of Relationship between Selfefficacy in Research and Research Performance of Dental Student, of Yazd Dental College in 2014. The Journal Of Medical Education and Development. 2015;10(2):129-37.

25. Tiyuri A, Saberi B, Miri M, Shahrestanaki E, Bayat BB, Salehiniya H. Research self-efficacy and its relationship with academic performance in postgraduate students of Tehran University of Medical Sciences in 2016. Journal of education and health promotion. 2018;7.

26. Wright $A B$, Holttum $S$. Gender identity, research self-efficacy and research intention in trainee clinical psychologists in the UK. Clinical Psychology \& Psychotherapy. 2012;19(1):46-56.

27. Lambie GW, Vaccaro N. Doctoral counselor education students' levels of research self-efficacy, perceptions of the research training environment, and interest in research. Counselor Education and 
Supervision. 2011;50(4):243-58.

28. Garavand H, Kareshki H, Ahanchian M. The Relationship between Self-efficacy in Research and Research Performance A study on Students of Medical Sciences University of Mashhad. Iranian Journal of Medical Education. 2014;14(1):41-51.

29. Baltes B, Hoffman-Kipp P, Lynn L, Weltzer-Ward L. Students' Research Self-Efficacy during Online Doctoral Research Courses. Contemporary Issues in Education Research. 2010;3(3):51-8.

30. Bierer SB, Prayson RA, Dannefer EF. Association of research self-efficacy with medical student career interests, specialization, and scholarship: a case study. Advances in Health Sciences Education. 2015;20(2):339-54.

31. Black ML, Curran MC, Golshan S, Daly R, Depp C, Kelly C, et al. Summer research training for medical students: impact on research self-efficacy. Clinical and translational science. 2013;6(6):487-9.

32. Phillips JC, Russell RK. Research self-efficacy, the research training environment, and research productivity among graduate students in counseling psychology. The Counseling Psychologist. 1994;22(4):628-41.

33. Ramin MR, Aghazadeh M. Research self-efficacy in the psychology and educational sciences graduate students. Research in Curriculum Planning. 2014;10(9):147-55.

34. Casuso-Holgado MJ, Cuesta-Vargas Al, Moreno-Morales N, Labajos-Manzanares MT, Barón-López FJ, Vega-Cuesta $M$. The association between academic engagement and achievement in health sciences students. BMC Medical Education. 2013;13(1):33.

35. Yu L, Shek DT, Zhu X. The influence of personal well-being on learning achievement in university students over time: Mediating or moderating effects of internal and external university engagement. Frontiers in psychology. 2018;8:2287.

36. Criollo M, Romero M, Fontaines-Ruiz T. University students' self-efficacy for learning how to conduct research. Psicologia Educativa. 2017;23(1):63-72.

37. Lambie GW, Hayes BG, Griffith C, Limberg D, Mullen PR. An exploratory investigation of the research self-efficacy, interest in research, and research knowledge of Ph. D. in education students. Innovative Higher Education. 2014;39(2):139-53.

38. Ashrafi-Rizi H, Najafi NSS, Kazempour Z, Taheri B. Research self-efficacy among students of Isfahan University of Medical Sciences. Journal of education and health promotion. 2015;4.

39. Saral DG, Reyhanlioğlu D. An analysis of educational faculty students' research self-effıcacy in terms of a number of variables. Procedia-Social and Behavioral Sciences. 2015;174:1138-45.

40. Aryani E, Narimani A, Kamangar K, Omidvar A. The role of gender in research self-efficacy of nursing students. Iran Journal of Nursing. 2015;27(92):1-12.

41. Götzfried A. Women, science and technology: Measuring recent progress towards gender equality. Science and Technology. 2004;9(94):34-45.

42. Mac Giolla E, Kajonius PJ. Sex differences in personality are larger in gender equal countries: Replicating and extending a surprising finding. International Journal of Psychology. 2018. 
43. Weisberg YJ, DeYoung CG, Hirsh JB. Gender differences in personality across the ten aspects of the Big Five. Frontiers in psychology. 2011;2:178.

44. Wetzel AP, Mazmanian PE, Hojat M, Kreutzer KO, Carrico RJ, Carr C, et al. Measuring medical students' orientation toward lifelong learning: a psychometric evaluation. Academic medicine. 2010;85(10):S41-S4.

45. Adedokun OA, Bessenbacher AB, Parker LC, Kirkham LL, Burgess WD. Research skills and STEM undergraduate research students' aspirations for research careers: Mediating effects of research selfefficacy. Journal of Research in Science teaching. 2013;50(8):940-51.

46. Bieschke KJ, Bishop RM, Garcia VL. The utility of the research self-efficacy scale. Journal of Career Assessment. 1996;4(1):59-75.

47. Greeley A, Johnson E, Seem S, Braver M, Dias L, Evans K, et al. Research Self-Efficacy Scale: Unpublished scale. Pennsylvania State University, University Park. 1989.

48. O'Brien K, Malone M, Schmidt C, Lucas M, editors. Research self-efficacy: Improvements in instrumentation. American Psychological Association Conference, San Francisco; 1998.

49. Holden G, Barker K, Meenaghan T, Rosenberg G. Research self-efficacy: A new possibility for educational outcomes assessment. Journal of Social Work Education. 1999;35(3):463-76.

50. Mullikin EA, Bakken LL, Betz NE. Assessing research self-efficacy in physician-scientists: the clinical research appraisal inventory. Journal of Career Assessment. 2007;15(3):367-87. 